\title{
Teacher Attitudes and Beliefs in Language of Instruction in a Desegregated School Environment in South Africa
}

\author{
Nomalanga P. Grootboom, PhD \\ University of South Africa \\ grootbnp@unisa.ac.za
}

Doi:10.5901/mjss.2014.v5n23p1064

\begin{abstract}
This study mainly aimed to describe the attitudes of teachers in a former "whites only" school of South Africa. The attitude was determined towards the language on instruction and the learner's proficiency in English. The data was gathered interviews, documents and observation. On the other hand, the Afrikaans speaking white learners are taught in their mother tongue, Afrikaans while the Black learners are taught in Afrikaans their mother tongue. The perception of these white teachers is that the Black learners cannot cope with the language of instruction which is Englsih, and that they should be taught in their own native languages a situation very much like apartheid or segregation. Therefore desegregation per se does not lead to predictable and meaningful changes in the attitudes of groups to each other and can, in fact, lead to the heightening of tension and prejudices.
\end{abstract}

\section{Introduction}

The Bantu education system was designed by the architects of apartheid to control the aspirations of Black South Africans and school them for subservience. The Bantu education system and its initiative failed. South Africa became increasingly ungovernable and needed systematic change (Dolby, 2001).

The 1990s ushered in a new political era characterised by the unbanning of political parties, such as the African National Congress (ANC); the release of political prisoners, notably Nelson Mandela; the shift of political power from the minority National Party to democratically-elected government lead by the ANC. Since the change in government, there has been a concerted effort to transform the education system from the one marred by racial, gender and class inequities to a more equitable one (Mabokela, 2000). Since the first democratic elections in 1994, a process of racial desegregation began in South African schools. Given the historical experience of South Africa and other countries attempting similar transformations, the expectation was that simply mixing students from different racial groups in one school would result in racial conflict and violence unless the structures and processes of schooling were changed at the same time (Harber, 2004).

In the aftermath of apartheid, it is pivotal that teachers, parents and students learn to function within diverse populations and within multicultural settings. The attitude and belief of those who are expected to be implementers of polices of transformation in education have or do so with the

\section{Literature Review}

Desegregation in former White schools aimed at redressing the legacy of the racially and ethno-racially fragmented, dysfunctional and unequal education system inherited from apartheid. Under the system of apartheid, there were separate schools for African, White, Indian and Coloured (mixed race) children. The education provided was not only separate; it was unequal, with spending heavily in a biased way towards White children. Black South African children received least of all (Christie, 1991).

One of the visible transformational initiatives in South African schools was school desegregation, when former White schools admitted Black learners, thus adopting Constitutional stipulations and the South African Schools Act (SASA, 1996). Desegregation as a transformational initiative essentially followed the dictates of the freedom charter to "open doors to all learners and cultures" (The Freedom Charter, 1955).

Fundamentally, Jansen (1990) acknowledges that integration is not merely about changing the racial demographics of the learner and educator bodies. Desegregation, compared to integration, means transforming the educational landscape by attending to a range of discriminatory practices: sexism, racism, xenophobia, and ethnicity. It means seeking to construct curricula and texts that are informed by demographic ethos. It requires teachers, school managers and communities to provide a democratic environment (Dolby, 2001). 
It is apparent that the provision of equitable education inclusive and representative of the diverse cultures of South Africa is not only necessary but also essential. It has become necessary for South Africans to respect diverse cultures and to eliminate all forms of discrimination. This is a mandate, and education has an important role to play (Ntshoe, A 1991). Not only is the South African Government hoping for more cooperation and democratic practices in desegregated schools, it also hopes to promote cross-cultural and positive racial interactions (Lynch, 1992, as quoted in Harber, 1998). To reach these goals requires a methodology to answer questions about the actual experiences of learners during the process of desegregation. The methodology outlined in the next chapter provides us with the guiding principles for this.

The current study will explore the ways teachers respond to the experience of teaching Black learners from different linguistic backgrounds. How schools adapt to increased numbers of Black students is critical to building a nonracist, non-sexist South Africa. This study examined what the white teachers say about teaching in English to black learners and continue to teach Afrikaans to their white Afrikaans speaking learners in South Africa.

Few studies have considered representing the voices of learners in the newly desegregated school system in South Africa.

\section{Method}

Qualitative methods were used in this study to understand the cross-racial interactions among learners in a South African school. The qualitative research design employed here used a case study approach and presented collected data as narration. The goal is that the study will contribute to theory, educational practice, policymaking and social consciousness. (Mc Muller \& Schumacher, 2001). The central research question examined by this study is the following: What are the attitudes and experience of teachers in a desegregated environment of Black and White learners in former "Whites only" school of South Africa?

Merriam (1988) argues that the researcher's role in case study research is central. Face-to-face interviews were usedthis paper is derived out of a larger study that was done for the purposes of exploring the cross-racial interaction of Black and White Learners in $U$ school in Pretoria at school named.I selected the grade eleven classes in the school as the sample for this study based on the fact that they have spent a reasonable amount of time in the desegregated experience but, at the same time, still can benefit from further changes.

\section{Findings}

It is important to note that the school has a faculty of 44 teachers and all of them are Afrikaans-speaking and Whites. There is not a Black teacher on the premises.

In an interview with a female Black student, she stated that they asked the principal why the school did not have a Black teacher. He replied that he hired one, but the teacher could not stay. The reason he said was given as an explanation for leaving was that there was too much work, and she could not handle it.

One of the teachers (T1) shared the following information:

This teacher, the only one with a doctoral degree in Afrikaans at this school, suggested in an interview that the Black children in the school should be taught in their mother tongue. The teacher (T1) said in an interview:

"I firmly believe that the Black English speaking learners will get better Mathematics results and Physical science results if people learn via their own language.....their mother tongue: and I think it's a problem in our country that you haven't got "Is Zulu and Susana"... [Setswana] you see all of those people go to school in [he meant to say township or rural school] Even at Primary level they start to use English and they cannot cope."

The teacher continued by saying -

"I really think quite a lot of them don't simply understand the language well enough to learn subjects like Mathematics properly and therefore I think there is a great deal of benefit if you could learn through your own mother tongue those kinds of subjects. I think not enough is being done for home language schools and...later on in your career it doesn't matter that much coz their probably [because] our second language or third language skills will be developed well enough to cope."

The Afrikaans teacher blamed lack of cross-racial interaction between the Afrikaans and English speaking students on the differences between their language background, one of the reasons why they do not mix and interact.

One of the teachers, who suggested that Black students should be taught in their mother tongue, also remarked 
that Black people will think it is "sort of apartheid again," meaning that mother tongue instruction would be taking Black learners back to the segregated schools in the apartheid era." His contention seems to be promoting the idea that language proficiency is the main reason that Black learners are not achieving. "Well, it was like that in the apartheid era, worst still the black kids were compelled to be taught in Afrikaans."

There are differences noted by the learners, and there is the history of the learner's influences, as to how the Black learners are treated and the White learners were given preferential treatment. In an interview a Black learner attributes the resistance to change at this school to the historical occurrences of the past and present segregated structure of the schools. "Half the time we do not what they are saying. Even at assembly they speak in Afrikaans."

This suggests that there is more at play here than just language proficiency. The student saw the injustice of having all Afrikaans speaking teachers, but the teacher, however, failed to see the different mismatches between home languages and languages of learning, teaching techniques in this school, and the learners' preferences. The learners had a non-compromising attitude about the opportunities available in the world of work if they were taught in English. They knew the disadvantages they have for achieving their set goals in the future if they were taught in Afrikaans or any of the indigenous languages. "The world is English," said one Black learner, expressing a preference for English as the language of learning and teaching (LOLT).

When the Afrikaans speaking learners were asked if it is a problem to have English speaking Black learners in their school they all said, "Yes, it is". The White learners had an impression that the school was an institution for Afrikaans speakers. The White learners uniformly gave the above answer.

On arrival at this school, the teachers and the principal explained to me that structurally this was a parallel medium. As I spent more time at the school it was clear that the prevailing environment and what was clearly promoted was Afrikaans. In explaining the structural design of the classroom in Grade 11 an Afrikaans speaking learner explained in the following manner:

"We are actually Afrikaans people; Afrikaans learners are separate from English learners.

We are only together in our registered (sic) period, but, yeah, you can say we sometimes, we do mix sometimes".

The learners were aware of the separate classrooms and the limited opportunities for Black and White students to interact. Despite the Government's commitment to multilingualism and the promotion of language rights in all spheres of public life, this school does not totally reflect multilingual South Africa.

Another example from an interview was when an Afrikaans speaking learner said what he understood the school to be and expressed what sounded as though the Afrikaans speakers were making a compromise to the extent that the school is allowing Black English speaking learners to be at the school. In an interview, during which Afrikaans learners explained how they got to the school one said, "I wanted to be in an Afrikaans school..." He repeated, "I just wanted an Afrikaans school. "I'm Afrikaner".

Categorisation seems to provide White authorities with a comfort zone where they can label all non-Afrikaans students as English speakers instead of recognising them as Black or African. One day in the staff room I overheard teachers talking in Afrikaans and referring to "Engelsprekende kinders" (English speaking children) To these Afrikaans speaking White teachers identifying with the school is important, and it seems that this comforts him to know that he is an Afrikaner in a school that is dominated by Afrikaans speaking staff members and that the school is structured to separate English and Afrikaans speakers.

The existence and dominance of Afrikaans in the school suggests that the teachers are using the power of Afrikaans to privilege one group of students over the others. The Black learners are well aware of the school's history and they see as racist the continued dominance of Afrikaans as the LOLT in the school.

An Afrikaans teacher and his colleagues suggested that Black learners should be taught in their African languages because they believe "they might understand better." I shared with him what the Afrikaans learner said that Afrikaans was fading away and that the Afrikaans language will be lost because everyone seems to want to speak English. The teacher defended with vigour the need to retain the Afrikaans language.

The lingua franca, like they say it, is becoming English, the language of use, but I really think that they speak from their point of view and this is a parallel medium school, but if you can speak to somebody say in Waterkloof [High School] where one has only Afrikaans only then you might get another view point, and they also say that because and they might be right then, the Universities tend to assume English much more than in the past......"

When I asked which instruction one respondent was referring to, he said in response:

"Ja, except like the University of the Northwest and Potchefstroom campus, where you've got quite a strong contingent 
of Afrikaans and the Universities policy is also quite outspoken to their specific campus to retain Afrikaans, not that they will refuse English students, but they will... Like they say, protect the Afrikaans character of that University."

This teacher did not believe that the Afrikaans speaking learners at this school expressed fear that Afrikaans did not have competing value with English. He was sure that Afrikaans is kept alive in the Universities he mentioned. Another Afrikaans colleague explained to me that they did not want to lose their culture and language. They blamed the government for introducing measures that were not practicable. The principal said, in the school's year book, "I really think that my colleagues in the Department do not know what they are doing."

Other teachers (T1, T2, and T3) shared the same view of retaining their own language as a priority, emphasising the fact that English speaking Black learners were losing their culture and language by being in the former White schools. There is a general fear of losing one's language, particularly the Afrikaans language. The teacher, supported by the school structure of separate classrooms for English and Afrikaans speakers, explained why the school structure has created a segregated environment, keeping to its apartheid ethos and sustaining it (Naidoo, 1996).

In an interview, the Afrikaans speaking teachers emphasized that an effort is made to keep the Afrikaner culture in place. "We are fighting," said one Afrikaans White teacher. "We even do it outside the school. We go to the laager to keep Afrikaans alive". There is also a false pretext of sympathising with the English speaking Black learners by claiming that they were not coping with the English language that is their medium of instruction and that they are losing their "tribes" and culture. Another teacher (T2), professing knowledge of the past, also makes reference to Black people's identity as belonging to tribes. "They are losing their tribes when they come here" she said. Black people would remain in their "reserves;" residential areas that were designed by the Apartheid laws.

The last-mentioned statement by Teacher 2 is clearly meant to nurture the patterns of the past when the Broederbond formed the Federation of Afrikaner Cultural Organizations (FAK), following the example provided by the Christian National Education Schools (CNO schools), to develop a sense of pride and accomplishment in the Afrikaans culture. Segregation seems to be a preference at the school despite the government mandate to open doors to all learners and cultures. Instead of using a language policy to the advantage of all learners, the school, through the attitudes of the teachers and with its educational practices, is in conflict with new theories on how to assist learners who may not be proficient in English (Sipho, 2006).

For the Afrikaans teachers and learners the Afrikaans language stands at the centre of their goal and their emphasis is on ethnicity. This expression seems to be a symptom of their fear of losing their language. The School Governing Body (SGB) governs the management of its school and, among other responsibilities, decides the language policy of the school, which, according to the Department of Education, must promote multilingualism. The teacher's remarks about the learners appeared to be an expression of low expectations about Black learners: "They cannot cope with the language." Meaning it is far from their comprehension. But with the Afrikaans learners it was all smooth sailing according to the teachers

From observation it was clear that there is an overrepresentation of Black learners in subjects like travel and tourism and arts class. The White Afrikaans chooses Accounting and stated that the Black learners were not competent in English, but that the Black learners were however doing well in Afrikaans, which was the Information Technology (IT) class. There was only one Black learner in an IT class. The grade 11 classes are made up of three classes of Black English speakers (134) and two classes of Afrikaans speakers. This allows the School Governing Body (SGB) to choose a language of Instruction for the learners and the SGB chooses a language that represents the Afrikaans learners. This is a violation of Black learners' rights by not including one or two of the indigenous languages.

\section{Language, Power, and Privilege}

There are two fundamental sources from which language derives its power, namely the ability of the individuals or groups to realise their intentions by means of undermining the marginalised indigenous languages. The school under study seems not to give any official recognition to the nine indigenous languages and instead recognises English and Afrikaans only. Language empowerment is the ability of individuals or groups to impose their agendas on others (disempowerment of the latter).When a language is representation of culture and the agendas too can be facilitated through Afrikaans (Foley, 2003).

An Afrikaans White speaking learner made a point about the fading away of Afrikaans language. Meanwhile the Afrikaans teacher (T1) continued to make a point that the Afrikaans speaking universities are and will remain a strong contingent of Afrikaner Dom. This teacher reaffirmed ideas of segregation, which supported ideologies of the old apartheid South Africa that emphasised competence in one's mother tongue. Several teachers taught the Black learners 
as a subject area and second language. Expressing a camouflaged concern I found this a double standard in terms of which language is promoted. The Afrikaans language was advocated by the Afrikaans teachers and $100 \%$ of the teachers are Afrikaans speaking. The SGB also is dominated by Afrikaans speakers who reinforce the commitment to instruction in that language. In trying to find out who has to make compromises in the effort to advance this process of inclusion, the teacher stated

I think the government should do more A...maybe money must be funded, because what we have at this stage is either Afrikaans speaking schools or English speaking schools. We don't have schools or if we have them it's a big minority of schools with other Africans languages are predominate and...as the main language of the school the language of teaching at the school and I think what should be done to get schools say Zulu as the main language.

He continued to say, as follows:

"I don't know if people will say that puts us a little bit back to the apartheid system. I hope they don't say it like this.... What I see especially for people is to learn the different learning areas or subjects through their own home language because..."

The Afrikaans learners have the advantage of being taught in Afrikaans by Afrikaans teachers. The Teacher said: in referring to Black learners, added the following: "I am sure they will master it better, [referring to Black learners], but now they've got to learn through English and not all of them cope with English. Does this help cross-racial interaction, not the way the suggestion goes?" This remark emerged from a meeting that was held in the morning where one of the teachers expressed a concern about how English-speaking learners were not coping when taught in the medium of English. Again, it does not look like he realised he had no competence in the language himself, and some of the Afrikaans speaking teachers were struggling with English as their second language.

The teachers were so overwhelmed with an influx of Black learners in their school. The expression that the Black learners were not coping because they are taught in English contrasts with what one teacher said, about the Black learners doing well in Afrikaans language as a subject area. Both English and Afrikaans are third or fourth language for some of the Black learners especially those who come from indigenous language backgrounds. One wonders whether the same thing could be said about the Afrikaans learners. This does not appear to be helping cross-racial interaction?

When I asked this Afrikaans teacher about the cross-racial interaction of the students he confirmed that there was none, he said the following:

I think there is not enough interaction. I even see it here where we do have different cultures in the same school, which they stay too much in their own groups. I think they don't interact, as they should with exception.

A Black learner stated the following when referring to the cross-racial interaction:

No I think (he pauses) because they... we the English Black learners we try our best to be friendly to them but they, they don't want that or they don't do the same.

My day-to-day interactions with the learners revealed that English and Afrikaans speaking learners did not see eye to eye on many socio-political issues, including race and racism. "When they speak negatively about Mandela, I tell them he is my uncle," said a Black English speaking learner. I was struck by their lack of interaction at break (recess). The learners would go in different directions and group themselves along racial lines - obviously Black or White groups. It was during the interview session that the learners expressed their deepest concerns and appeared to have been happy to have a chance to talk about the subject. One learner asked if I wanted to see their classroom. She said there are different classes: White and Black. "There [are] English and Afrikaans only classes, they are different", she said in the hallway while she was helping me to find the Life Orientation teacher. They seemed to know that because the school used to be an Afrikaans school it has a reputation of being racist. While learners and adults talked about racism, no one addressed the racism inherent and hidden in the act of denying the use and recognition of indigenous home languages at the school.

Language of instruction does not seem to be structured so that it promotes or encourage cross-racial interaction. One teacher said in an interview, "there are too many languages."

\section{Language of Instruction and the Future}

In an interview, a Black learner expressed his feeling about Afrikaans by making me aware that the world was becoming 
English. There is a general believe among learners (especially Black learners) that the world is becoming English. English and Afrikaans learners expressed similar opinions about the importance of English and Afrikaans as their medium of instruction. The Afrikaans learner had the following to say about how she understands the popularity of English: "Everyone wants to speak English, even in an Afrikaans school."

The future of English as the language of business was a motivating factor to the English speaking learners, causing them to want to be taught in English rather than Afrikaans. In his prediction the same English speaking learner said, "If I was Afrikaans I would go to English class because once you leave our school, the world so English, it's a recognised language, so I think it's more of a disadvantage towards them [Afrikaans learners]."

In trying to find out who has to help in an effort to promote this process of inclusion a White Afrikaans speaking teacher had the following to say: "I think the government should do more because, what we...maybe money must be funded, because what we have at this stage is we have either Afrikaans speaking schools or English speaking schools".

While the new Constitution of South Africa recognises the break of marginalising various aspects of life, this Afrikaans teacher chooses to ignore the changes in other languages, especially those which were not recognised as important. He made suggestions which belong to the character and organisation of the divide and rule practices of the apartheid regime. He still believes the school should be separated:

"We don't have schools or if we have it's a big minority schools with other Afrikaans languages and...as the main language of the school the language of teaching at the school and I think what should be done to get schools, say, Zulu as the main language."

The teacher seems to ignore the consequences of the apartheid era. During morning meetings, teachers discuss problems and concerns they have in the classroom. In particular, a bilingual teacher at this school (which means she speaks both English and Afrikaans) had a concern she posed by faculty meeting where they discuss their day to day agenda.

The Afrikaner's ethos is retained through the maintenance of Afrikaans language and philosophy of life. She claimed that Black learners were not coping when taught through English. Another teacher remarked that former White schools are becoming $90 \%$ Black. She further stated as follows:

"We are fighting." This teacher explained that the Afrikaans speaking people were fighting to retain their Afrikaans language. "We organise meetings. We do it even during public holidays."

Again it does not appear that he realised he had limited competence in the language himself. When I asked this teacher about the cross-racial interaction of the learners, he confirmed that there was none. "I think there is not enough interaction. I even see it here where we do have different cultures in the same school, which they stay too much in their own groups. I think they don't interact, as they should with exceptions." He agrees that there is no interaction as a result of the language differences, but suggests a further perpetuation of Black learners being taught in their mother tongue (each of the nine official indigenous languages).

In an interview with a Life Orientation Teacher, the teacher explained that the values and practices of Afrikaans and English speaking learners are different. They are different because of the language background and other factors like socio-economics status. South Africa has had a racially divided past, which means the learners have to adjust to each other and co-exist side by side in the classroom. About the behaviour of learners the following was said: 'The Afrikaans learners are more peaceful. "Hulle is nie" voedig.

There are two or more ways that subject choice is relevant in the present data. First, the learners are deprived of learning challenging and substantial course, which will lead them to intellectual career field. There is no History at the school and yet the subject would help me with a combination of my subject to choose law as a career field. "I wanted to be a lawyer." said the Black learner.

Secondly, they are tracked into following softer subject careers, which will take up employment into lesser challenging careers, like travel and tourism. The Black learners are not allowed to choose subject areas for learning at Grade 11 and 12. The school allows those in Grade 10 to choose the subjects they want to take in class but, when they get to Grade 11, the parents lose the opportunity to help their children to make choices in relation to their career aspirations because the school decides as to who has to go into subject areas because the school allows teachers to do the subject or learning choice for the learners. . I spoke to the teacher who helps the learners in this regard, she said: "We look at their performance and make a selection for them".

A Black learner stated, 
"Before I came to the U school, I was at a school where we are (sic) truly mixed and when I came to this [one] there was such racial segregation. I did not understand why... because I did not live through apartheid, so why should I be angry at people?"

The learners complained that the language used in the school is Afrikaans. The Black learners' parents do not understand Afrikaans and at the parents meetings they are left behind because of the language barrier. A learner said, "Our parents come to school for parents meetings and Afrikaans is spoken all the way. Even when they pass jokes our parents do not understand them. "

The explicit expression of dissatisfaction of these black learners explains two fundamental sources from which language derives its power, namely the ability of the individuals or groups to realise their intentions by means of forcing it on others. Language empowerment or, conversely, the ability of individuals or groups to impose their agendas on others results in disempowerment of the latter. "I did not think the school will handle the idea of many languages. I am saying this because of the surroundings where we live-Centurion, Pretoria, Tshwane, it will never work" said a Black English speaking learner from those interviewed.

\section{Discussion}

In this school there is a document that indicates that there are learners from most parts of South African provinces and other countries of the world. It posits that all things are beginning to be relatively equal in the linguistic distribution or might turn out to be even more divergent in the next decade or so.

Thus, despite the apartheid government's policy of separating South Africans according to their ethnic and language orientation, the language distribution still shows a remarkable diversity (see Chisholm and Mahomet study). In turn, any bilingual education programme in South Africa will have to take into consideration the distribution of languages. The school under study seems to be encountering and adjusting to an influx of learners not only from different races, but also from different linguistic backgrounds. In an explanation, this student expressed some excitement in realising that they are becoming a majority.

In matric, we will be the first matric where there is more than one English class because our grade is the only grade where it dominates Afrikaans. I guess that's why we are so good.

A learner stated the following when making reference to the cross-racial interaction:

No I think.....because they, we the English learners we try our best to be friendly to them but they, they don't want that or they don't do the same if you look in the classes there is always that beef (crowd). There is always that separation. That is when we divide in groups, there and there (she points at groups). You will never find this huge clan of guys and girls chatting, doing stuff together, the separation.

The Black learner continues to express despair as to what she understands is an answer to what she sees as possibilities of cross-racial interaction at the school. "They at a different level (a Black learner referring to White learners). It's not level per se, it's a different mind-set." There is emphasis of differentness in the learners. She repeatedly says they are different. "They are on a different mind-set," she said with emphasis. When asked about their experience in the school, the learner said, "There's always that separation". She continues: "Separation. That's where we divide into groups.

Separation seems to be emphasised by the learners. They even say it in different ways and different words. A "register class" is a class where black and white learners meet for fifteen minutes and to register their names for the day. This is the only time when black and white learners meet. This structure was put in place by the principal, who in an interview explained that by introducing the register class, it will contribute to the integration process for the school. In my observation the register class conflict often occurs in the register class as well as in sports interaction.

I observed discussions spearheaded by the Afrikaans speaking males, Black males and females. White Afrikaans female speakers were passive in this register class. In an interview they said they choose not to talk because the class always ends up rowdy and in conflict. One Afrikaans speaking learner said that the Black female learners were loud, and rowdy. "You know they are very loud and we do not like it," said one Afrikaans learner referring to Black learners.

When asked how learners perceive what they see the situation to be a Black English learner said the following in an interview: "White people do not want to change. They will remain that way. At an assembly when a Black learner has faulted they announce in Afrikaans what the learner has done."

Another Black learner stated, "The discussion was such that they insist on doing 'fiery'. Their parents are racist. They are simply ignorant". 
In an interview, the White Afrikaans speaking learner explained that the school for her is average. She is not too excited about being at school. She also complains about teachers yelling at the learners in a Mathematics class. A Black English speaking learner mentioned challenges of culture and how the teachers handle these conflicts between learners of different racial groups. White Afrikaans learners said, "Its different cultures, we are also stereotyped, they generalise us."

The register class helps but it is designed to last for just 15 minutes a day. She continued, and said, "It is a momentary thing". The learner sees the act by the Principal as "racist". The problem is that they do they understand the occurrence of being "racist" and the impact thereof. I asked to get clarity as to what she meant by "they". The Afrikaans speaking learner's perception of the school is different from that of the English speaking Black.

In an interview, a Black English speaking learner gives an account of what happens when the students fight and how the school handles learners in conflict. He said, "Fights break out between Black and White. The Principal takes sides. It is useless to report a case to the Principal because the Principal takes sides with White learners."

Socially, it's to a point where they will say something. You will hear by the way they speak that they said something very hurtful. And they will say it in Afrikaans. I don't understand why they don't have the audacity to say it in English.

This unfair behaviour demonstrated by people in authority appears to make conflict grow into a silent epidemic. A Black male learner discussed his experience with White learners as follows: "Those who play rugby have a superiority complex because they think they are better than Black learners".

From this discussion it appears that Black English learners perceive the cultural notions of teaching as authoritarian, that is the style of discipline. The teachers spend much of the class time yelling and using words that were very disturbing to the ear. Time for instruction was spent on reprimand. The opportunity to learn is lost because of lack of time and classroom management. I was in class for observation when a teacher yelled, "Shut up! Shut your big mouth". It appears that the culture of authority is authoritarian and racist. The majority of discipline was applied to Black learners. Whereas the Afrikaans speaking learners have a different relationship with this authority oftentimes it is a cordial relationship. Occasionally Afrikaans speaking learners call the teachers the 'tannie' whereas the relationship of teachers with Black learners appears to be authoritarian.

Another example was given by Black English speaking female learners who mentioned that the rugby players bullied everyone in the hallway during class intervals. This behaviour was brought to the attention of the Principal. Nobody took action against the rugby players. When on-going racial conflict occurs and the teachers yell at the learners, the register class does not serve its intended outcome. If, in fact, the learners are to express their differences and learn to cope with their experiences; this does not appear to be occurring. Thus positive cross-racial interaction is impossible especially when they are kept in separate classrooms for most of their school days and they have only fifteen minutes of the register class.

The English speaking Black learners are disillusioned but stay focused on getting an education. The statement "We come to learn" was repeated a number of times. In one instance, the Black English speaking learners said how difficult it is for their parents to believe them when they tell on their White teachers.

At break time the learners are conspicuously divided into groups. White Afrikaans speaking learners are on one side and Black learners on the other side. These learners break into segregated several are on one side of the and Black English speaking learners are on the other side of the classroom at this school. Stereotyping remarks from teachers were reported by several Black English speaking learners from teachers: "Ek is gatvol" "you Blackies" were commonly used reprimand or words of discipline. "I do not understand you; you are blank faces' the learners quoted the Principal in his Economic class. The Black English learners said in a conversation when they explained how they got to be taught by the Principal: "We were kicked out of class because the teachers did not like some of us."

The White Afrikaans speaking learners realise how protected they are at the same time they know how hostile the other teachers are towards the Black learners. "Hulle is rusistig-[Afrikaans language meaning, they are racist] Passive resistance and isolation results when segregation forbids the learners from getting to know each other, accepting and embracing each other's differences.

The teachers are not aware of what is happening across cultures. Their interest is guarding against losing power and pressure on their own Afrikaans language. One Black learner remarked about the learners' response to the situation in which they find themselves. "They do not stand up for themselves." This is in response to a teacher who advised him to leave school. "He is racist," said the learner. "If I were a White learner he would advise me to go to his class, however he advised me to leave the school". In observing whether other cultural norms are treated, I found disrespect for other people's differences, whilst the way of life of the Afrikaans speaker was fully displayed.

Black learners understand the structural history of the school under study. One Black learner explains it in this manner: "The school was known to be racist. They changed to a parallel medium." If you were to count the total amount 
of all the assemblies that have taken place and the entire announcement, how many times have they spoken in English and how long do they speak English? It does not compare with the racial way they do Afrikaans. Black learners made the following observation:

"I think because the school was built as an Afrikaans school, and that they speak to us in a language that they understand. They try to resist but there are those who open up.

When the Black English speaking learners comment on the historical background, they attribute the fact that the teachers are all Afrikaans speaking, which results in a lack of cross-racial interaction. I grew to know the students better, from day to day. I was often moved by their lack of interaction at break. I also observed a situation when they go home. It was during the interview session that the learners expressed their deepest concerns and appeared to have been happy to have a chance to talk about the subject. They said they knew that the school was Afrikaans only and that it was racist.

The school was originally built as Afrikaans school as a result the teachers are Afrikaans. In 2000 when the first English class was accepted; and then to Grade 9 and 10, on racial background - meaning Black learners were accepted in the school. It is still there (racism).

A number of variables, such as scheduling, learning areas, discipline, attendance and promotion policies, testing practices, extracurricular activities, are further generated by policy and are mainly symbolic and representative of the Afrikaans culture. It is interesting to observe which language is mainly used in implementing the said variables. The relationship the student and the teachers in the classroom and out of the classroom was examined as an area of cross racial interactions.

Some of the internal organisational variables are influenced by the staff and faculty and the Afrikaans Head of Department for Grades 10,11, and 12. The Afrikaans teachers must themselves implement what they themselves have no understanding of, said the Principal in an interview. I observed that the teachers apply disciplinary measures at the school to keep order. Despite the school's official agenda, discipline appears to be a priority.

In an interview with a Black English speaking learner, she said the following:

They try to include us, but sometimes you feel the difference. You sense that no, we're not included as the White people are. Let's say the Afrikaners, because yes, we are in an Afrikaans-English speaking school unless you're speaking half the things are mostly in Afrikaans and then the others are in English.

A Black female prefect had the following to say about her relationship with White Afrikaner teachers:

There is favouritism for the Afrikaans. There is a lot of favouritism. The teachers are more relaxed with them referring to the Afrikaans learners, more on to, you know, "This is the work, l'm going to do something else." As with us, they will not. They do not trust us. They do not trust us, really. I feel they do not trust us, but I mean, we are all not mischievous.

On how discipline of students was handled, Black learners said the following:

The Afrikaans classmates act up just as much as we do but our thing is more blown up into a huge thing because there's also at that level where, you know what, these are English speaking children or something like that. l'm not sure what's going on exactly but ours is blown up into a more thing. Afrikaans learners are mischievous just as much as we are.

The Principal replied, "You must understand that that these teachers are handling Black learners for the first Time". Time. "The instruction between Afrikaans and English classes is completely different. The race hierarchies in the two different classes are prevalent in the school. Black English learners are in the majority in the English language class whereas white learners are taught in their separate classes in their mother tongue- Afrikaans. White learners were taught by a White Afrikaans speaking teachers.

The Afrikaans speaking teachers complained about the influx of Black learners into "their schools". They stated and that these Black English speaking learners were not doing well, that they are struggling with the English language. There was no indication that this remark referred to all learners.

I explained the advantages created by the way the school is structured. The awareness of the student and the kind of treatment they receive from the school and their White counterparts that create a problem for cross-racial interaction. A female Black English Learner reported the following:

Social interaction, Black and White, you know we get along. We do get along to a certain extent but I mean, even now as a prefect and youth counsel, you interact with them but there's still that barrier of "You know what, I'm not going to be seen with you anymore or something like that but you talk and you have fun and you - but there's still that kind of thing that's there and I don't know why it's there. 
The idea of Afrikaans teachers frequently construed the Black learners' cultural behaviour as disobedience. A Black female prefect explained what the principal said to the English speaking Economics class. "When we look down they do not understand, they reprimanded us, saying; 'Look me in the eye." There is a lack of cultural understanding that feeds this problem: "There is an understanding by English speaking African learners. Mr R tries to support. He reads from the Bible at assembly English and Afrikaans is used".

"The parents are resistant as well". A female learner had an Afrikaans female friend whose father would not allow her to be visited by this Black female learner. This school was pronounced as a religious school but no choice is made for other religious backgrounds. I wanted to find out about religion, and how there was no religious diversity - a teacher told me: "We tell the parents that this is a Christian school."

One Black learner made this observation.

"I found in the school that nobody stands up for themselves, they leave things to happen, even when they are treated in a racist manner."

An Afrikaans speaking teacher, as he passed where I was standing and speaking with a student, asked, when he saw the boy outside, the teachers remark was. "Why don't you leave school"?

It seems that teaching is repressive. It is like a military camp. Teaching appears repressive in Black or English speaking classrooms. In my observation all the learners kept looking at me to possibly observe whether I was paying attention - or whether I see what they see. The teacher struggled to use English. Black learners seemed to be happy that I was an eyewitness to what is happening in the classroom.

\section{Conclusion}

It seemed as if the Black learners were happy to see me at the school. I was the only Black professional and despite the 1993 Constitution's insistence that the state was required to promote the equal use and enjoyment of all 11 official languages (Constitution, 1993, section 3.1) there was an undeniable shift towards mono-lingualism in the public sphere, with the effect that English is increasingly emerging as the lingua franca. Soudien (1997) points out that, until there is an inclusive programme of language learning and education, all of the conditions of cultural oppression will remained visible. $\mathrm{Du}$ Toit (1995) takes the view that the opening of schools to all races does not automatically ensure mutual understanding and acceptance between educators and learners and amongst learners. Therefore desegregation per se does not lead to predictable and meaningful changes in the attitudes of groups to each other and can, in fact, lead to the heightening of tension and prejudices. I found this claim to be true in the occurrences at the school under study. Within the desegregated school spaces was dynamically constructed with language playing a significant role. Where there is little or no social interaction and the school did not promote it, the classes in two languages kept the learners apart. This appeared to be another strategy of power play between groups (Van Heerden, 2000).

\section{References}

African National Congress (ANC): White Paper of Education (1995): Department of Education. Pretoria: The Children's Charter of South Africa (Adopted by Children's Summit of South Africa, 1 June 1992).

Christie, P: (1993): School desegregation and curriculum in South Africa: A study, in Taylor (Ed) inventing knowledge: Cape Town.

Dolby, N. (2001). Constructing Race-Youth, Identity and Popular Culture in South Africa State University of New York Press

Jansen, J. (1990). Curriculum as a political phenomenon: Historical reflections on Black South African Education. The Journal of Negro Education, 59(2), 195-206

The Freedom Charter (1955) (in.... http://www.anc.org.za/show.php?id=28) 2001).

Harber, C. "Redress and Process: Educational Reform in the New South Africa," in Lene Buchert, editor, Education Reform in the South in the 1990s (Paris: UNESCO, 1998), pp. 75-87

Mabokela, R.O (2000): Voices of Conflict: Desegregating South African UniversitieS Palmer Press. Marshall and Rossman.

Armstrong, A., \& Foley, P. (2003). Foundations for a learning organization: organization learning mechanisms. Learning Organization, the, 10(2), 74-82.

Lynch, 1992 as quoted in Harber, 1998: . Harber, C. (1998). Desegregation, racial conflict and education for democracy in the new South Africa: A case study of institutional change. International review of education, 44(5-6), 569-582.

Soudien , C(1997)) Sayed, Y., Soudien, C., \& Carrim, N. (2003). Discourses of exclusion and inclusion in the South: Limits and possibilities. Journal of Educational Change, 4(3), 231-248. 